\title{
PENGARUH DOSIS PUPUK KANDANG SAPI TERHADAP SIFAT FISIK DAN KIMIA TANAH PADA TANAMAN KACANG TANAH (Arachis Hypogaea L.)
}

\author{
Viktor Viegas Platini Wawo \\ SMU.N. 1 No.13, Kab. Ende, Jalan Udayana \\ VWawo@gmail.com
}

\begin{abstract}
ABSTRAK
The Effect of Dosage Organik Fertilizer on Physical Properties and Land Chemistry in Soan Beans (Arachis Hypogaea L.). This Research Aims To: Determine The Effect Of Cow Manure Does On Soil Physical Properties Of Peanut Plants. Knowing The Effect Of Cow Manure Does On Soil Chemical Properties In Peanut Plants. To Know Optimum Dose Of Cow Manure Can Affect Physical And Chemical Properties Of Soil Peanut Plant.

The treatments used in this study were Pk0 (0 Ton Ha-1 or without Cow Manure), Pk1 (10 Ton Ha-1 Cow Manure), Pk2 (20 Ton Ha-1 Cow Manure), Pk3 (30 Ton Ha- 1 Cow Manure, Pk4 (40 Ton Ha-1 Cow Manure). The Observing Variables in This Study are Soil Physical Properties Variables, which include Bulk Density (G Cm-3) and Total Soil Pore Space (\%), And Soil Chemical Properties Variables That Cover N-Total Soil, P-Soil Available, K-Available Soil, C-Organic Soil, And Ph Soil. Research Results Show That Giving Cow Cage Fertilizer in Peanut Plants In General Has an Effect of Improving Soil Physical Properties in the Form of Increasing Soil Volume Weight and Total Soil Pore Space, Giving Cow Cage Fertilizer in Peanut Plants Generally Affecting Improving Soil Chemical Properties in the Form of Increasing N-Total , P-Available, K-Available, C-Organic And Soil Ph As Well As The Optimum Dose Of Cow Manure That Can Improve The Physical And Chemical Properties Of Soil In The Best Peanut Plants Are 40 Tons / Ha.
\end{abstract}

Keywords: Cow Manure, Soil Physical Properties, Soil Chemical Properties, Peanuts

\section{PENDAHULUAN}

Kacang tanah (Arachis hypogaea L.) merupakan tanaman kacang-kacangan yang menduduki urutan kedua setelah kedelai, berpotensi untuk dikembangkan karena memiliki nilai ekonomi tinggi dan peluang pasar dalam negeri yang cukup besar. Kebutuhan kacang tanah di Indonesia mencapai 2,1 juta ton sedangkan produksi nasional baru mencapai 837.495 ton pada tahun 2004 (BPS Indonesia, 2006). produksi kacang tanah propinsi NTT pada tahun 2009 yaitu 22.465 ton kemudian pada tahun 2010 mengalami penurunan $10,6 \%$ atau total produksi 20.069 ton (BPS NTT, 2011). dan berdasarkan data dari dinas pertanian kabupaten Ende produksi kacang tanah mencapai 228 ton dengan luas panen 168 ha. atau rata-rata produksi $1.357 \mathrm{~kg}$ ha ${ }^{-} 1$, pada hal disisi lain potensi hasil dari varietas kacang tanah berkisar antara 1,5 ton $\mathrm{ha}^{-1}-2,5$ ton ha ${ }^{-1}$ biji kering (adisarwanto, dkk. 1993).

Hasil kacang tanah di Indonesia dapat mencapai $3.664 \mathrm{t} \mathrm{ha}^{-1}$ biji kering (Lana, 2007), dan hasil ini masih dapat ditingkatkan. Potensi hasil varietas unggul dapat mencapai 2,6 $\mathrm{t} \mathrm{ha}^{-1}$ biji kering. Nugrahaeni dan Kasno (1992) menyatakan bahwa hasil kacang tanah baru mencapai 1,45 $\mathrm{t} \mathrm{ha}^{-1}$ biji kering, masih lebih rendah dibanding dengan potensi hasil varietas unggul. Sumarno dkk., (1989) menyatakan 
bahwa $66 \%$ kacang tanah di Indonesia ditanam di lahan kering dengan rentang hasil antara 0,5 hingga 1,5 $\mathrm{t} \mathrm{ha}^{-1}$ biji kering. Hasil (polong kering) kacang tanah di lahan kering masih jauh lebih rendah $2 \mathrm{t}$ $\mathrm{ha}^{-1}$ dibanding dengan hasil kacang tanah di lahan basah yang dapat mencapai 4,5 t $\mathrm{ha}^{-1}$ (Balitkabi, 1999). Salah satu masalah yang menyebabkan rendahnya hasil kacang tanah di lahan kering karena sebagian besar lahan kering mempunyai tingkat kesuburan rendah dan sumber air terbatas, hanya tergantung pada curah hujan yang distribusinya tidak dapat diatur sesuai kebutuhan tanaman, selain itu adanya degradasi lahan sehingga menyebabkan kandungan unsur hara dan C-orgnik dalam tanah yang sangat rendah. Upaya untuk mengatasi hal diatas dapat dilakukan pemupukan dengan pupuk organik kandang sapi. Menurut Sutanto (2002) pupuk organik merupakan bahan pembenah tanah yang lebih baik daripada bahan pembenah buatan, walaupun pada umumnya pupuk organik mempunyai kandungan hara makro $\mathrm{N}, \mathrm{P}$ dan $\mathrm{K}$ yang rendah tetapi mengandung hara mikro dalam jumlah cukup yang sangat diperlukan dalam pertumbuhan tanaman. Secara lebih spesifik keuntungan dari penggunaan pupuk organik antara lain: memperbaiki struktur tanah, sumber unsur hara bagi tanaman, menambah kandungan humus tanah, meningkatkan aktifitas jasad renik, meningkatkan kapasitas menahan air, mengurangi erosi dan pencucian nitrogen terlarut, meningkatkan kapasitas tukar kation dalam tanah, meningkatkan daya sangga terhadap perubahan drastis sifat tanah, meningkatkan kerja mikrobia tanah dalam proses dekomposisi bahan organik dan menambahkan bahwa pupuk organik akan membentuk senyawa kompleks dengan ion logam yang meracuni tanaman seperti $\mathrm{Al}, \mathrm{Fe}$, dan $\mathrm{Mn}$ (Sarief, 1989). Pupuk kandang sapi merupakan pupuk organik yang dapat memperbaiki struktur tanah, meningkatkan daya pegang air, menambah unsur hara, meningkatkan kapasitas tukar kation dan meningkatkan mikroorganisme tanah karena mengandung C-organik yang tinggi, unsur hara yang lengkap, mudah diperoleh dan murah.

Pupuk kandang sapi sebagai sumber bahan organik memiliki kelebihan jika dibandingkan dengan pupuk anorganik seperti (1) pupuk kandang sapi dapat meningkatkan kadar bahan organik tanah, (2) meningkatkan nilai tukar kation, (3)memperbaiki strutur tanah, (4) meningkatkan aerasi dan kemampuan tanah dalam memegang air dan (5) menyediakan lebih banyak macam unsur hara seperti nitrogen, fosfor, kalium dan unsur mikro lainnya serta (6) penggunaannya tidak menimbulkan dampak negatif terhadap lingkungan. Selain kelebihan tersebut pupuk kandang sapi juga memiliki kekurangan antara lain : (1) kandungan unsur haranya yang rendah, (2) tersedia bagi tanaman secara perlahanlahan sehingga membutuhkan waktu yang lebih lama, (3) membutuhkan biaya transportasi yang besar (Sarief, 1989 ).

Pupuk organik merupakan pupuk alternatif yang telah benyak dikenal dikalangan petani dan saat ini sedang diupayakan oleh para peneliti untuk mengetahui sifat dan karakteristiknya guna dimanfaatkan secara efisien sesuai dengan kebutuhannya. Pupuk kandang sapi merupakan pupuk organik yang memperbaiki sifat fisik dan kimia tanah karena mengandung C-Oranik yang tinggi, unsur hara yang lengkap, serta menguntungkan karena mampu memperbaiki status kesuburan tanah. 
Secara kimiawi pupuk kandang sapi yang baik mengandung bahan organik $60-70$ $\%$, nitrogen $1,5-2 \%$, kalium $0,5-1 \%$ dan kadar air $30-40 \%$ (Marsono dan Sigih, 2000).

Hasil penelitian Jatmiko (1997), mendapatkan bahwa dengan penambahan pupuk kandang sapi sampai $20 \mathrm{t} \mathrm{ha}^{-1}$ menyebabkan menurunya nilai berat volume tanah, meningkatkan kemampuan menahan air dan meningkatkan air tersedia dibandingkan dengan tanpa penambahan pupuk kandang sapi. Pupuk kandang sapi apabila digunakan dengan tepat maka hasil tanaman dapat ditingkatkan.

Berdasarkan uraian di atas, maka akan dilakukan penelitian dengan judul. Pengaruh dosis pupuk kandang sapi terhadap sifat fisik dan kimia tanah pada tanaman kacang tanah (Arachis hypogaea L.).Penelitian ini bertujuan untuk Mengetahui pengaruh dosis pupuk kandang sapi terhadap sifat fisik tanah pada tanaman kacang tanah.

\section{METODOLOGI PENELITIAN}

Percobaan ini dilaksanakan di kebun BPP Kecamatan Nangapanda, Desa Ndeturea, Kabupaten Ende. Kondisi tanah di kebun percobaan memiliki pH tanah 5,5 (masam), C- organik tergolong rendah dengan nilai $1,25 \%$, N-total tergolong rendah dengan nilai $0,17 \%$, $\mathrm{P}$ - tersedia tergolong rendah dengan nilai 10,89 \% ppm, K-tersedia tergolong rendah dengan nilai 123,5 ppm dan memiliki tekstur tanah lempung berdebu (Lampiran 1.). Percobaan ini dilaksanakan mulai bulan September-Desember 2012.

Bahan-bahan yang digunakan dalam percobaan ini adalah benih kacang tanah, dan pupuk kandang sapi.Alat-alat yang digunakan adalah pacul, sabit, ajir, ember plastik, sekop, timbangan, oven, meteran, penggaris, tali raffia, kantong plastik, alat tulis, dan kamera.

\section{Rancangan Percobaan}

Rancangan yang digunakan dalam percobaan ini adalah Rancangan Acak Kelompok (RAK) dengan pola faktor tunggal yang terdiri dari lima perlakuan yaitu :

$\mathrm{PK}_{0} \quad$ : 0 ton $\mathrm{ha}^{-1}$ atau tanpa pupuk kandang sapi

$\mathrm{PK}_{1} \quad: 10$ ton $\mathrm{ha}^{-1}$ pupuk kandang sapi

$\mathrm{PK}_{2}$ : 20 ton $\mathrm{ha}^{-1}$ pupuk kandang sapi

$\mathrm{PK}_{3} \quad: 30$ ton $\mathrm{ha}^{-1}$ pupuk kandang sapi

$\mathrm{PK}_{4}$ : 40 ton $\mathrm{ha}^{-1}$ pupuk kandang sapi

Semua perlakuan diulang sebanyak empat kali sehingga terdapat 20 petak percobaan.Denah percobaan disajikan dalam gambar 3.1.

\section{Pelaksanaan Penelitian \\ Persiapan lahan}

Tanah tempat dilaksanakan percobaan dibersihkan dari sisa-sisa tanaman maupun kotoran lainnya dan dicangkul sebanyak dua kali sedalam \pm 30 $\mathrm{cm}$ agar gembur, kemudian dibagi menjadi empat ulangan dan masing-masing ulangan dibagi lagi menjadi 5 petak dengan ukuran masing-masing petak sebesar $2 \mathrm{~m}$ x $1 \mathrm{~m}$. Tinggi guludan $30 \mathrm{~cm}$, jarak antar petak 50 $\mathrm{cm}$ dan jarak antar ulangan $100 \mathrm{~cm}$. Denah tata letak petak percobaan di lapangan disajikan pada Gambar 3.1.

\section{Penanaman}

Penanaman dilakukan secara tugal pada kedalamana $\pm 3 \mathrm{~cm}$ dengan jarak tanam $40 \mathrm{~cm}$ x $20 \mathrm{~cm}$ (Adisarwanto dkk, 1993), sehingga pada setiap petak percobaan terdapat 25 tanaman. Benih dimasukan ke dalam lubang tanam sebanyak 4 biji lubang ${ }^{-1}$ dan setelah tumbuh dijarangkan dengan mempertahankan 2 tanaman lubang ${ }^{-1}$. Tata 
letak dan jarak tanam tanaman dalam petak percobaan dapat dilihat pada Gambar 3.2.

\section{c.Pemberian perlakuan pupuk kandang sapi.}

Pemberian perlakuan pupuk kandang sapi dilakukan pada saat satu minggu sebelum tanam dan diberikan secara merata pada setiap petak percobaan sesuai dengan dosis perlakuan. Dosis pupuk kandang sapi adalah $0 \mathrm{t} \mathrm{ha}^{-1}(0 \mathrm{~kg}$ petak $\left.^{-1}\right), 10 \mathrm{t} \mathrm{ha}^{-1}\left(2 \mathrm{~kg}\right.$ petak $\left.^{-1}\right), 20 \mathrm{t} \mathrm{ha}^{-1}(4$ $\mathrm{kg}$ petak $\left.^{-1}\right), 30 \mathrm{t} \mathrm{ha}^{-1}\left(6 \mathrm{~kg}\right.$ petak $\left.^{-1}\right), 40 \mathrm{t} \mathrm{ha}^{-}$ ${ }^{1}\left(8 \mathrm{~kg}\right.$ petak $\left.^{-1}\right)$.

\section{Pemeliharaan tanaman}

Pemeliharaan tanaman meliputi penyulaman, penjarangan, penyiangan, pembumbunan serta pengendalian hama dan penyakit. Penyulaman dilakukan pada biji yang tidak tumbuh normal tujuh hari setelah tanam. Penyulaman dilakukan dengan menggunakan bibit kacang tanah yang telah ditanam bersamaan pada petak yang dibuat untuk pembibitan. Setelah tanaman tumbuh dilakukan penjarangan dengan menyisakan 2 tanaman lubang ${ }^{-1}$. Penjarangan dilakukan dua minggu setelah tanam. Penyiangan dan pembumbunan dilakukan bersamaan setelah tanaman berumur 3 minggu dengan tujuan untuk menghilangkan gulma yang tumbuh disekitar tanaman.

\section{Panen}

Panen kacang tanah dilakukan padatanggal 13 desember 2012 dengan kriteria $75 \%$ daun-daun tanaman sudah menguning dan polong sudah tua. Tandatanda polong siap panen adalah berwarna coklat dan keras serta bila dibuka biji telah berisi penuh dan kulit biji sudah kelihatan tipis dan berwarna hitam.

Teknik Pengambilan Sampel Untuk Analisis Sifat Fisik Dan Kimia
Teknik pengambilan sampel tanah pada setiap petak perlakuan tanaman kacang tanah dengan cara menggali pada sembilan titik yang sudah di tentukan di setiap petak. Setiap petak percobaan tanaman kacang tanah digali tanahnya dengan kedalaman $\pm 20 \mathrm{~cm}$. Pada setiap galian tanah di ambil tanahnya $1 \mathrm{~kg}$ kemuduan di komposit. Dari hasil tanah yang dikomposit itu di ambol lagi sebanyak $1 / 2 \mathrm{~kg}$ untuk dijadikan sampel tanah pada setiap perlakuan sehingga diperoleh 20 sampel tanah.

\section{Variabel Pengamatan}

\section{Variabel sifat fisik tanah}

1. Berat volume tanah (bulk density) (g $\mathrm{cm}^{-3}$ ) Berat volume tanah diamati saat panen. Pengambilan sampel tanah dilakukan menggunakan sistem komposit dengan menggunakan metode ring sampel pada kedalaman 0-20 $\mathrm{cm}$. Sampel tanah lalu dianalisis di laboratorium Ilmu Tanah, Fakultas Pertanian, Universitas Udayana, Denpasar.

2. Total ruang pori tanah (\%)

Total ruang pori tanah diamati saat panen. Pengambilan sampel tanah dilakukan menggunakan sistem komposit dengan menggunakan metode ring sampel pada kedalaman $0-20 \mathrm{~cm}$. Sampel tanah lalu dianalisis di laboratorium Ilmu Tanah, Fakultas Pertanian, Universitas Udayana, Denpasar.

\section{Variabel sifat kimia tanah}

1. N-total tanah.

N-total tanah diamati saat panen. Pengambilan sampel tanah dilakukan menggunakan sistem komposit, selanjutnya tanah dikeringkan lalu diayak sampai halus untuk dianalisis 
di laboratorium menggunakan metode Kjeldahl.

2. P-tersedia tanah

P-tersedia tanah diamati saat panen. Pengambilan sampel tanah dilakukan menggunakan sistem komposit, selanjutnya tanah dikeringkan lalu diayak sampai halus untuk dianalisis di laboratorium menggunakan metodeBray ${ }^{-1}$.

3. K-tersedia tanah

K-tersedia tanah diamati saat panen.Pengambilan sampel tanah dilakukan menggunakan sistem komposit, selanjutnya tanah dikeringkan lalu diayak sampai halus untuk dianalisis di laboratorium menggunakan metode Bray $^{-1}$.

4. C-organik tanah

C-organik tanah diamati saat panen.Pengambilan sampel tanah dilakukan menggunakan sistem komposit, selanjutnya tanah dikeringkan lalu diayak sampai halus untuk dianalisis di laboratorium menggunakan metode Walkey dan Black.

5. $\mathrm{pH}$ tanah

$\mathrm{pH}$ tanah diamati saat panen. Pengambilan sampel tanah dilakukan menggunakan sistem komposit, selanjutnya tanah dikeringkan lalu diayak sampai halus untuk dianalisis di laboratorium menggunakan $\mathrm{pH}$ meter (perbandingan tanah dan air 1 : 25)

\section{Analisis Data}

Data hasil pengamatan yang diperoleh merupakan data hasil analisis laboratorium dari setiap sampel tanah yang dikumpulkan secara komposit. Data di sajikan dalam bentuk tabel dan diagram.

\section{HASIL DAN PEMBAHASAN Sifat Fisik Tanah.}

$\begin{array}{rcr}\begin{array}{r}\text { Berdasarkan } \\ \text { laboratoriumberat }\end{array} & \text { hasil } & \text { analisis } \\ \text { volume } & \text { tanah }\end{array}$ mengalami peningkatan mulai dari kontrol sampai dengan perlakuan $\mathrm{PK}_{4}$. Beratvolume tanah yang tertinggi yaitu $1,193 \mathrm{gr} / \mathrm{cm}^{3}$ di peroleh pada perlakuan pupuk kandang sapi 40 ton ha ${ }^{-1}\left(\mathrm{PK}_{4}\right)$ lebih tinggi sebesar $14,83 \%$ pada perlakuan tanpa pupuk kandang sapi $\left(\mathrm{PK}_{0}\right)(\mathrm{Gambar}$ 4.1).

Menurut Fahmidin dkk, (2006), berat vulome tanah merupakan salah satu sifat fisik tanah yang paling sering ditentukan, karena keterkaitannya yang erat dengan penetrasi akar di dalam tanah, drainasedan aerasi tanah. Berat volume tanah selain dipengaruhi bahan organik juga di sebabkan oleh pengelolaan yang dilakukan terhadap tanah. Nilai berat volume terendah biasanya didapatkan di permukaan tanah sesudah pengolahan tanah. Tanah dengan bahan organik yang tinggi mempunyai berat volume yang rendah dan juga pada tanah dengan ruang pori total tinggi seperti tanah liat, cenderung mempunyai berat vulme yang rendah, sebaliknya tanah berstektur kasar, walaupun ukuran porinya besar namun total ruang porinya lebih kecil (Glossman dan Reinsch, 2002).

Berdasarkan hasil analisis laboratorium total ruang pori tanah mengalami peningkatan mulai dari kontrol sampai dengan perlakuan $\mathrm{PK}_{4}$. Kandungan total ruang pori tanah yang tertinggi yaitu $45,88 \%$ diperoleh pada perlakuan pupuk kandang sapi 20 ton $\mathrm{ha}^{-1}\left(\mathrm{PK}_{4}\right)$ atau lebih tinggi sebesar $14,84 \%$ dari total ruang pori tanah pada perlakuantanpa pupuk kandang sapi $\left(\mathrm{PK}_{0}\right)($ Gambar 4.1). Berdasarkan data tersebut bahwa peningkatan total ruang pori tanah dapat di pahami karena pupuk kandang sapi dalam tanah selain meningkatkan bahan organik tanah dapat 
juga berfungsi sebagai perekat dalam tanah.

pembentukan dan pemampatan agregrat

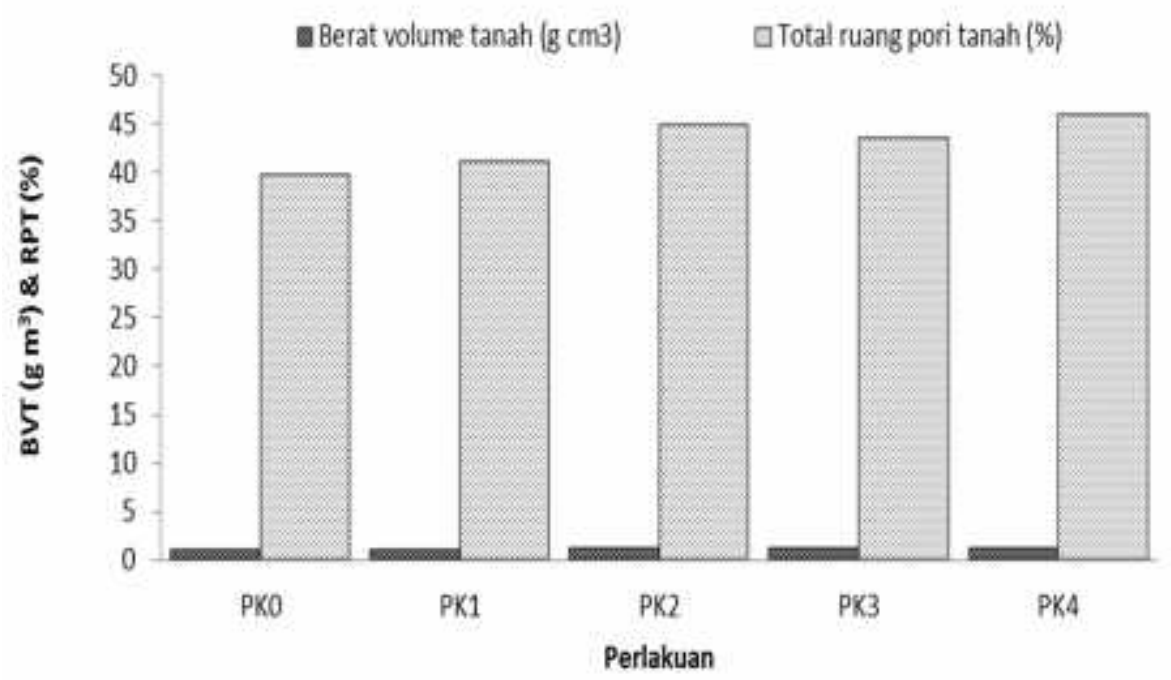

Gambar 4.1 Grafik Berat Volume Tanah dan Total Ruang Pori Tanah

\section{Sifat Kimia Tanah}

\section{N-total tanah}

Berdasarkan hasil analisis laboratorium N-total mengalami peningkatan mulai dari kontrol sampai dengan perlakuan $\mathrm{PK}_{4} \mathrm{~N}$-total tanah yang tertinggi yaitu $0,52 \mathrm{ppm}$ diperoleh pada perlakuan pupuk kandang sapi 40 ton $\mathrm{ha}^{-1}$ atau lebih tinggi sebesar $67,3 \%$ dari $\mathrm{N}$ - total tanah pada perlakuan tanpa pupuk kandang sapi $\left(\mathrm{PK}_{0}\right)$ (Gambarl 4.2.1).

Nitrogen merupakan satu unsur hara yang penting dan dapat disediakan melalui pemupukan. Meningkatnya dosis pupuk kandang sapi dari 10- 40 ton $\mathrm{ha}^{-1}$ mampu meningkatkan $\mathrm{N}$-total tanah. Hal ini disebabkan oleh kandungan $\mathrm{N}$-total yang lebih tinggi pada pupuk kandang sapi

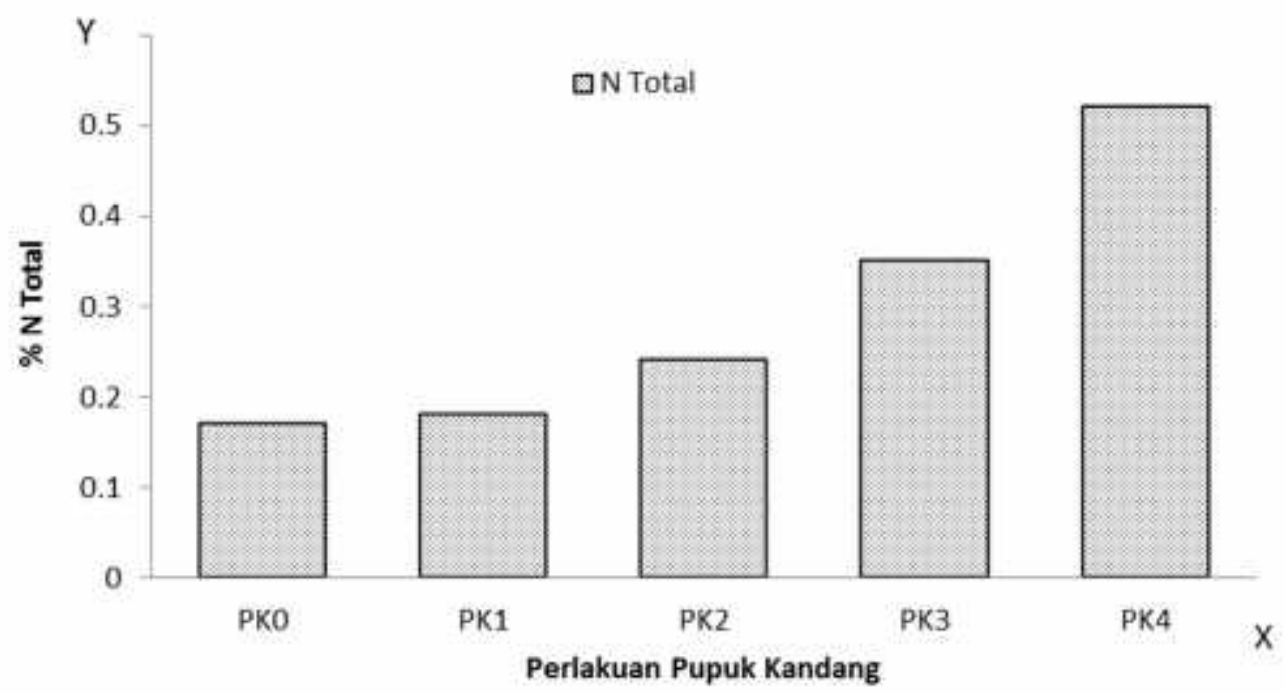

Gambar 4.2.1 Grafik Kandungan N-total (\%) 


\section{P-tersedia tanah}

Berdasarkan hasil analisis laboratorium kandung P-tersedia tanah mengalami peningkatan mulai dari kontrol sampai dengan perlakuan $\mathrm{PK}_{4}$ Kandungan P-tersedia yang tertinggi yaitu 56,17 ppm di peroleh pada perlakuan pupuk kandang sapi 40 ton ha $^{-1}\left(\mathrm{PK}_{4}\right)$ atau lebih tinggi sebesar 55,97 \% dari kandungan P-tersedia pada perlakuan tanpapupuk kandang sapi $\left(\mathrm{PK}_{0}\right)($ Gambar 4.2.2).

Hal ini disebakan semakin tinggi dosis pupuk kandang sapi yang diberikan maka P-tersedia semakin tinggi.Menurut Buckman dan Brady (1982). Peningkatan P-tersedia tanah terjadi akibat pengaruh langsung dan pengaruh tidak langsung dari pemberian pupuk organik terhadap berbagai bentuk fosfat dalam tanah. Pengaruh langsung yaitu melalui dekomposisi bahan organik yang hasil

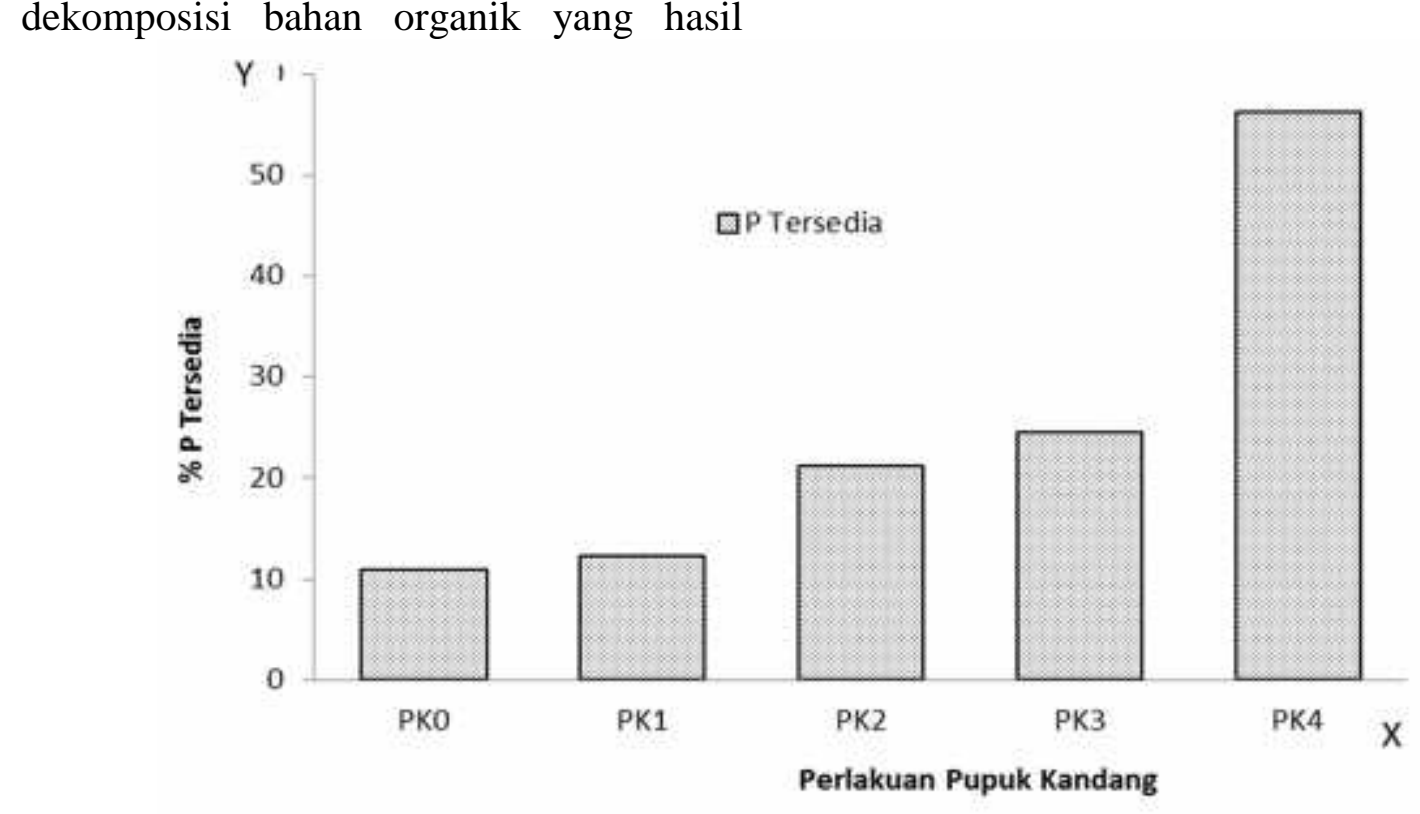

Gambar 4.3. Grafik Kandungan P-Tersedia dekomposisinya berupa asam-asam organik seperti asam humat yang mempunyai kemampuan menghelat $\mathrm{Fe}$ pada tanah masam. Jadi, hasil dekomposisi bahan organik memegang peranan penting dalam tersedianya fosfat an-organik bagi tanaman. Menurut Yusuf dkk (1988), bahwa secara garis besar Ptanah di bedakan atas Pan-organik dan Porganik. Fosfat dalambentuk organik, satu atau mungkin lebih atom hidrogen dari asam fosfat hilang karena ikatan ester dimana sisa hidrogen, seluruhnya atau sebagian diganti oleh kation logam. Kandungan Pan- organik di dalam tanah mineral selau lebih tinggi dari P-organik, kecuali pada tanah organik. Kadar P-organik pada tanah mineral selalu lebih tinggi terdapat pada top soil atau lapisan olah, karena adanya penimbunan bahan organik.

\section{K-tersedia tanah.}

Berdasarkan hasil analisis laboratoruim K-tersedia tanah mengalami peningkatan mulai dari kontrol samapai dengan perlakuan $\mathrm{PK}_{4}$. K-tersedia tanah yang tertinggi yaitu 123,5 ppm diperoleh pada perlakuan pupuk kandang sapi 40 ton $\mathrm{ha}^{-1}\left(\mathrm{PK}_{4}\right)$ atau lebih tinggi sebesar 58,29\% dari K-tersedia tanah pada perlakuan tanpa pupuk kandang sapi $\left(\mathrm{PK}_{1}\right)$ (Gambar 4.2.3) Berdasarkan data tersebut maka diasumsikan bahwa pemakain dosis pupuk kandang sapi semakin tinggi akan terus maningkatkan K-tersedia dalam tanah. Menurut Mulyani (1987), K lebih banyak dibutuhkan pada perkebunan-perkebunan karena sifarnya lambat tersedia. Hal ini bukan berarti $\mathrm{K}$ tidak dibutuhkan dalam 
tanaman semusim tetapi karena $\mathrm{K}$ segera tersedia hanya meliputi $1 \%-2 \%$ dari $\mathrm{K}$ total tersedia dalam tanah. Walaupun demikian $\mathrm{K}$ dalam larutan tanah lebih mudah di serap oleh tanaman tetapi lebih mudah juga terjadi pencucian

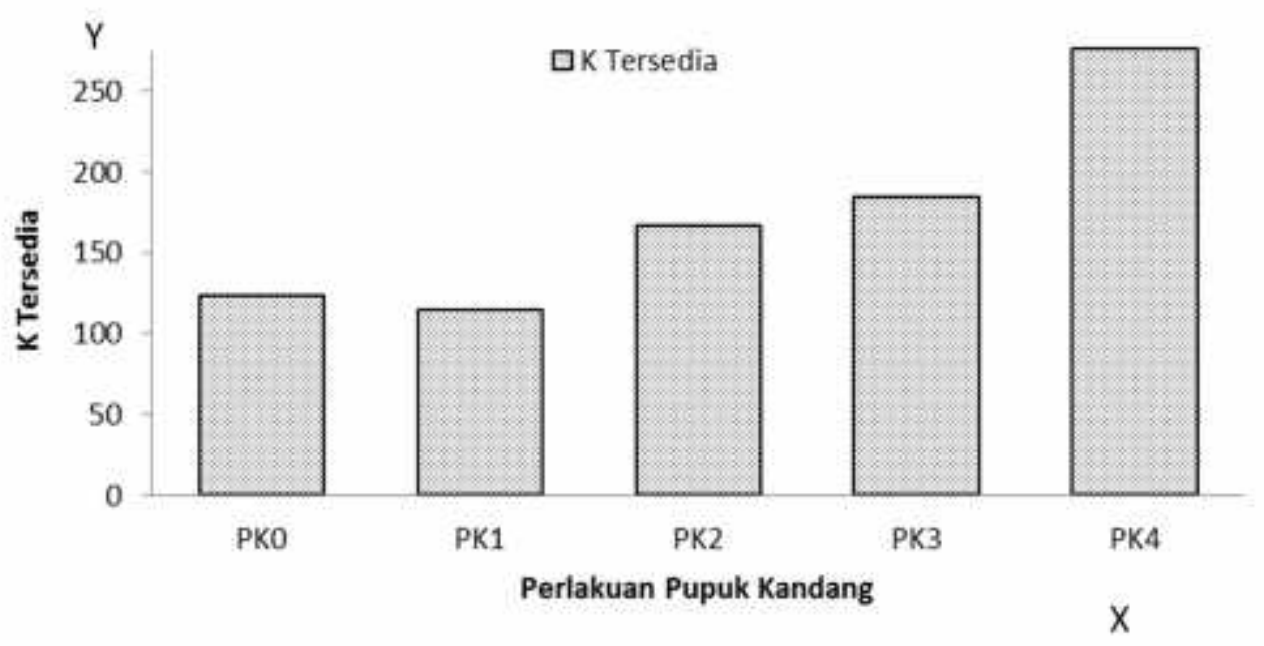

\section{C-organik Tanah}

Berdasarkan

Gambar 4.2.3 Grafik Kandungan K-tersedia

laboratorium $\mathrm{C}$-organik tanah mengalami peningkatan mulai dari kontrol sampai dengan perlakuan $\mathrm{PK}_{4}$. C-organik tanah yang tertinggi yaitu $3,51 \%$ di peroleh pada perlakuan pupuk kandang sapi 40 ton $\mathrm{ha}^{-1}$ $\left(\mathrm{PK}_{4}\right)$ atau lebih tinggi sebesar 64,38\% dari C-organik pada perlakuan tanpa pupuk kandnag sapi $\left(\mathrm{PK}_{0}\right)$ (Gambar 4.5). Menurut Apong dkk, (2007), denganpemberian 15 ton $\mathrm{ha}^{-1}$ pupuk kandang sapi memberikan nilai tertinggi terhadap C-organik tanah. Hal ini sesuai dengan pendapat Soepardi (1983), yang menyatakan bahwa tinggi atau rendah Corganik tanah di pengaruhi oleh bahan organik yang di tambahkan.

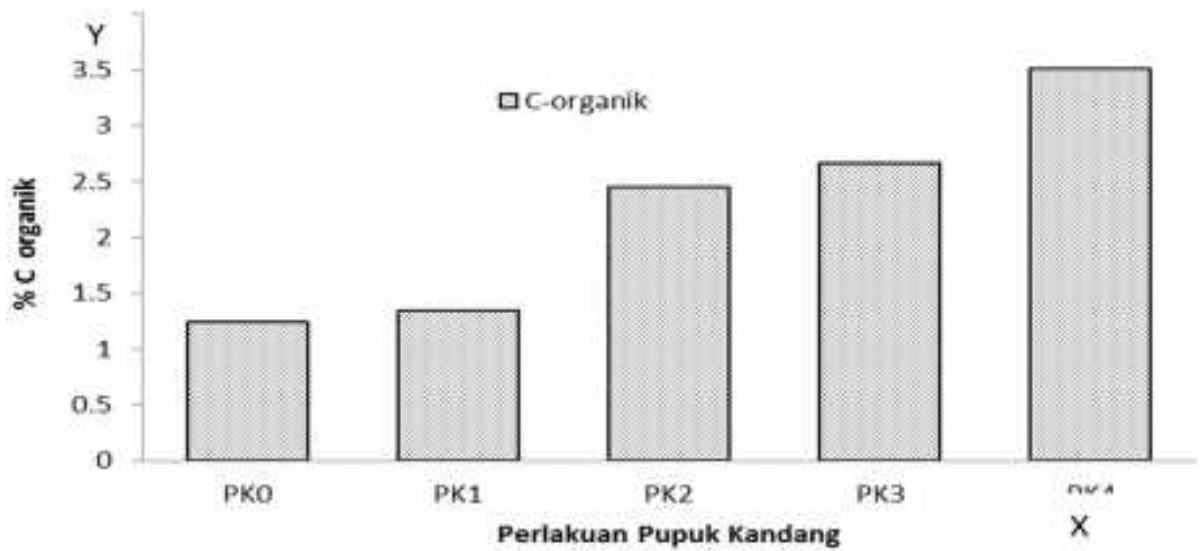

Gambar 4.5 Grafik Kandungan C-organik

Bahan organik di dalam tanah akan di uraikan oleh mikroorganisme tanah dan memanfaatkannya sebagai sumber makanan energi humus. Selanjutnya bahan organik akan mengalami mineralisasi dan dalam proses mineralisasi ini C-organik akan di ubah menjadi bahan-bahan organik lain yang dapat memperbaiki sifat fisik dan kimia tanah lainnya. Menurut Aribawa dkk (2007), penambahan pupuk organik pada tanah tidak selalu meningkatkan kadar Corganik bila dibandingkan dengan kadar C-organik tanah awal (sebelum di tambahkan pupuk organik) karena kadar 
C-organik tergantung pada jenis pupuk organik. Akan tetapi penggunaan bahan organik ke dalam tanah juga harus memperhatikan perbandingan kadar $\mathrm{C}$ terhadap unsur hara lain seperti N, P, K, karena apabila perbandingan sangat besar, bisa menyebabkan imobilisasi (Winarso, 2005).

\section{pH Tanah}

Berdasarkan hasil analisis laboratoroium $\mathrm{pH}$ tanah mengalami peningkatan mulai dari kontrol sampai dengan perlakuan $\mathrm{PK} 4 . \mathrm{pH}$ tanah yang tertinggi yaitu 6,6 diperoleh pada perlakuan pupuk kandang sapi $40 \mathrm{~kg} \mathrm{ha}^{-1}$ $\left(\mathrm{PK}_{4}\right)$ atau lebih tinggi sebesar 6,06 \% darikandungan $\mathrm{pH}$ tanah pada perlakuan pupuk kandang sapi 10 dan 20 ton $\mathrm{ha}^{-1}$ $\left(\mathrm{PK}_{1}\right.$ dan $\left.\mathrm{PK}_{2}\right)($ Gambar 4.2.5)

Peningkatan $\mathrm{pH}$ tanah disebabkan karena bahan organik yang digunakan sudah mengalami proses dekomposisiatau telah terdekomposisi lanjut (matang), karena bahan organik yang telah termineralisasi akan melepaskan mineralnya, berupah kation-kation basa. Sebaliknya apabila pupuk kandang sapi yang masih mengalami proses dekomposisi akan melepaskan asam-asam organik yang menyebabkan menurunnya pH tanah ( Suntoro, 2011; Cahayani dan Dewi, (1996). Apong dkk., (2007) melaporkan bahwa kotoran sapi merupakan salah satu pupuk organik yang banyak di gunakan oleh petani, mengingat banyak dan mudah mendapatkannya serta harganya murah di banding denga pupuk organik lainnya. Pupuk kandang sapi seperti pupuk kandang lainnya dapat berperan sebagai humus tanah, dengan demikian dapat membantu memperbaiki struktur tanah dan dapat meningkatkan $\mathrm{pH}$ pada tanah. Kadar pH tanah menentukan, mudah tidaknya tanaman dalam menyerap unsur hara, pada umumnya semakin nilai $\mathrm{pH}$ mendekati netral maka penyerapan unsure hara semakin baik. Percobaan ini menunjukkan bahwa setiap peningkatan dosis pupuk kandang sapi $\mathrm{pH}$ tanah cenderung meningkat. Peningkatan tersebut di akibatkan oleh bahan organik yang terkandung dalam pupuk kandang sapi memiliki gugus funsional yang dapat mengadorpsi kation lebih besar dari pada mineral silikat (Muliani dkk, 2007).

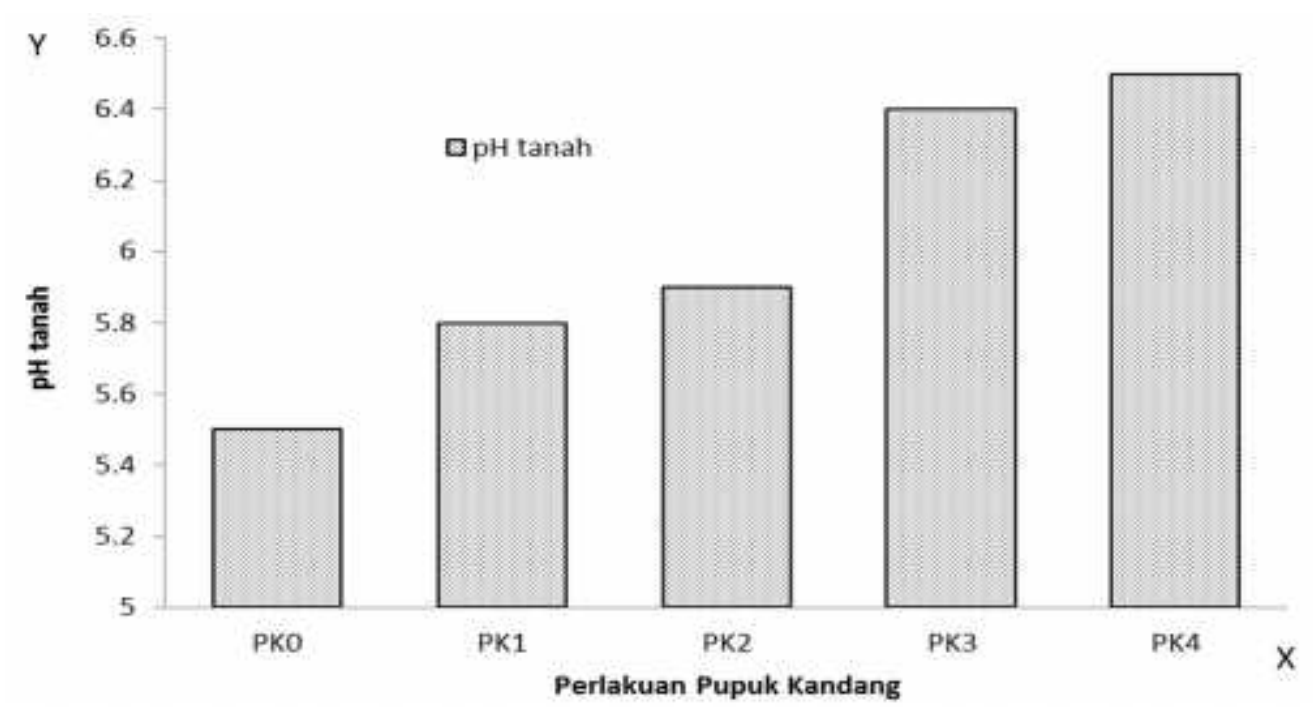

Gambar 4.2.5 Grafik Nilai pH Tanah

\section{KESIMPULAN}

Berdasarkan hasil penelitian dapat disimpulkan sebagai berikut :
Pemberian pupuk kandang sapi pada tanaman kacang tanah secara umum berpengaruh memperbaiki sifat fisik tanah berupa meningkatnya berat volume tanah 
dan total ruang pori tanah.Pemberian pupuk kandang sapi pada tanaman kacang tanah secara umum berpengaruh memperbaiki sifat kimia tanah berupa meningkatnya N-total, P-tersedia, K-tersedia, Corganik dan $\mathrm{pH}$ tanah. Dosis optimum pupuk kandang sapi yang dapat memperbaiki sifat fisik dan kimia tanah pada tanaman kacang tanah yang terbaik adalah 40 ton/ha

\section{DAFTAR PUSTAKA}

Adisarwanto, T., Rahmiana, A.A., Suhartina. 1993. Budidaya Kacang Tanah. Malang: Balai Penelitian Tanaman Pangan.

Apong, S., Emma T. S., Dan olyviati, M.2007. Pengaruh kompos sampah kota dan pupuk kandang sapi terhadap sifat kimia tanah dan tanaman jagung manis ( zea mays saccharata) pada fluventic eutrudeps asal jatinangor kabupaten sumedang. laporan penelitian dasa (LITSAR) UNPAD.

Aribawa, I. B., Kartini, N. L. Dan Kariada, I. .K. 2003. Pengaruh beberapa jenis pupuk organik dan pupuk urea terhadap sifat tanah dan hasil kacang panjang di lahan kering pinggiran perkotaan denpasar bali. Denpasar : balai pengkajian teknologi pertanian bali.

Balitkabi.1999. Laporan Tahunan Badan Penelitian dan Pengembangan Pertanian. Malang: Balai Penelitian Tanaman Kacang-kacangan dan Umbi-umbian (Balitkabi).

Danahue, R.L., Miller, R.W., and Shickluna, j. C. 1997. Soils an Introduction to Soils and Plant, Growth. New Jersey : Fourt Edition Prentice Hall, Inc. Englewood Cliffs, N. J. Xiii +626 p.

Dewi, W.S. 1996. Pengaruh macam bahan organik dan lama prainkubasinya terhadap status $\mathrm{P}$ tanah andisol. (thesis) yogyakarta. Giller, K.E.

Erniyani, K. 2011. Efektivitas Strain Bradyrhizobium Japonicum yang
Diisolasi dari Beberapa Lokasi di Ende terhadap Pembentukan Nodul dan Penambatan Nitrogen pada Tanaman Kedelai (Glycine Max L.). (Tesis) Denpasar : Universitas Udayana

Gomez, K. A. dan Gomez, A. A. 2007. Prosedur Statistik untuk Penelitian Pertanian.(Endang Syamsuddin dan Justika S. Baharsjah, Pentj). Jakarta: UI.

Glosman, R. B. And Reinch, T. G. 2002. Dalam Kurnia, U. Adimiharja, A., Agus, F., Dariah, A. 2006. Sifat Fisik Tanah dan Metode Analisisnya. Bogor: Penerbit Balai Besar Litbang Sumber Daya Lahan Pertanian. Badan Penelitian dan Pengembangan Pertanian Departemen Pertanian.

Jatmiko, H. 1997. Aplikasi Pupuk Kandang, Kentang dan Mulsa Plastik pada Regosol Bukit Pasir. Edisi Khusus. Malang : Balitkabi.

Kasno, A. 2007. Strategi Pengembangagn Kacang Tanah di Indonesia. Peningkatan Produksi Kacangkacangan dan Umbi-umbian Mendukung Kemandirian Pangan. Bogor: Badan Penelitian dan Pengembangan Pertanian. Pusat Penelitian dan Pengembangan Tanaman Pangan.

Lana, W. 2007."Pengaruh Dosis Pupuk Kandang Sapi dan Mikoriza terhadap Pertumbuhan dan Hasil Tanaman Kacang Tanah (Arachis hypogaea L.)di Lahan Kering" (Tesis). Denpasar: Universitas Udayana.

Lingga, P., Marsono. 2004. Petunjuk Penggunaan Pupuk. Seri Agritekno. Jakarta: Penebar Swadaya.

Marzuki, H. A. R. 2007. Bertanam Kacang Tanah. Edisi Revisi. Jakarta: Penebar Swadaya.

Mulyani, O., Sofyan, E. T. Apong, s. 2007. pengaruh (zea mays saccharata) pada fluventic eutrdepts asal jatinagor kabupaten sumedang. Laporan da (LITMUD) UNPAD 
Nugrahaeni, N., Kasno, A. 1992. Plasma Nutfah Kacang Tanah Toleran terhadap Cekaman Fisik. Prosiding Simposium Penelitian Tanaman Pangan III. Malang: Balai Penelitian Tanaman Pangan.

Soepardi, G.1983. sifat dan ciri tanah. Bogor : jurusan tanah. Fakultas pertanian IPB Bogor.

Stevenson, F.J. 1982. Humus Chmistry Genesis, Composition and Reaction. New York: Jhon Willey and Sons. New York.Universitas Brawijaya. Malang.

Stevenson, F.J. 1986. Cycles of soilcarbon, nitrogen, phosphorus, sulfur, micronutriens, New York: Jhon Wiley and Sons. 380 p.

Sugito, Y., Yulia, N. Ellis, N. 1995. Sistem PertanianOrganik. Malang : Fakultas Pertanian

Sumarno, Manwan, I., Syam, M. 1989. Grain Legumes Research Program. Bogor: CRIFC.

Sutanto, R. 2002. Penerapan Pertanian Organik. Kanisius.Yogyakarta.

Sarief, S. 1989. Kesuburan dan Pemupukan Tanah Pertanian. Pustaka Buana. Bandung.

Suntoro, W. A. 2003. Peran bahan organik terhadap kesuburan tanah dan upaya pengelolaannya. Surakarta : sebelah maret university press. 